\title{
The effects of logistics competency on performance
}

\author{
Kuo-Chung Shang* and Peter B. Marlow**
}

\begin{abstract}
Logistics and supply chain management has been elevated to a strategic level whereby firms can simultaneously achieve differentiation and low cost for sustained competitive advantage. Empirical studies have often concentrated on logistics management in developed Western countries, displaying a bias towards the USA. This study applies the competency approach to explore logistics in Taiwan. A survey of 1,200 manufacturing firms was undertaken in order to examine the relationships between logistics competency, logistics performance, and financial performance, using exploratory factor analysis and the structural equation modelling technique. Four logistics competencies, namely, integration and knowledge competency, customer focused logistics competency, measurement competency, and agility competency were identified. The research findings revealed that (1) logistics competency was significantly related to logistics performance but not significantly associated with financial performance, and (2) logistics performance was positively associated with financial performance. These findings also implied that logistics competency has an indirect effect on financial performance through logistics performance. This finding confirmed the "world-class" logistics competencies (i.e. positioning, integration, agility, and measurement) as identified by MSUGLRT (1995). In addition, it suggests that logistics competency in a huge geographic area such as America can have the same effect in a smaller geographic area such as Taiwan.
\end{abstract}

Keywords: Logistics management, Logistics competency, Structural equation modelling, Performance, Supply chain management.

Submission Date: 02/10/2007

Acceptance Date: 15/11/2007

"Professor, Department of Shipping and Transportation Management, National Kaohsiung Marine University, Nan-Tzu, Kaohsiung City, 811, Taiwan, ROC, E-mail: kuochung@mail.nkmu.edu.tw

${ }^{* * *}$ Corresponding author, Professor, Logistics and Operations Management Section, Cardiff Business School, Cardiff University, Cardiff, CF103EU,UK, Tel.: +44 (0) 292087 6764, Fax:+44(0) 292087 4301, E-mail: marlow@cardiff.ac.uk 


\section{Introduction}

Logistics and supply chain management (SCM) has been elevated to a strategic level whereby many firms can simultaneously achieve differentiation and low cost for sustained competitive advantage (Bowersox and Daugherty, 1995; Novack et al., 1992; Christopher, 1998). Executives are becoming increasingly aware of the importance of successful integration and the management of essential logistics competencies across members of the supply chain for determining the ultimate success of the single enterprise.

Research on an organization's specific resources, capabilities, or competencies (i.e. the resource-based view of the firm) has received much attention in the past decade, but very few published empirical studies on logistics competency have focused on the resource-based theory. As researchers have pointed out:

Surprisingly, despite the call for more theoretical and strategically oriented work in logistics, the resource based theory (RBT) of the firm and the related capabilities approach - which represent a dominant stream of research in strategic management over the last decade - have not been prominent in the logistics literature (Olavarrieta and Ellinger, 1997: 559).

In logistics studies which have adopted a resource-based approach, some have focused on the outcome of logistics such as cost, quality, flexibility, innovation, and delivery (e.g. Fawcett et al., 1996, 2000; Morash, 1996a, 1996b), while others have focused on the behaviour of logistics (e.g. Bowersox et al., 1999) such as integration, agility, and measurement. Those which have focused on the outcome of logistics have often viewed indices, such as cost or quality, as manufacturing strategies (Frohlich and Dixon, 2001) and employed these items as performance indices (e.g. Scannell et al., 2000). In contrast, those which have focused on the behaviour of logistics have found that firms' logistics behaviour leads to performance difference. Therefore, as far as the logistics and SCM field is concerned, analysis of behaviour-based competencies would appear to be the more appropriate research direction.

Additionally, in the last decade, Taiwan, the Republic of China, a small, resource-absent, densely populated island, has become a world-class supply source of electronic hardware products. 'Almost $60 \%$ of the world's desktop PCs were either made in Taiwan or contained a motherboard made by a Taiwanese company' (Ernst, 2000: 226). Nevertheless, how top manufacturing firms can maintain their success in an extremely competitive market is an ongoing question. Logistics may be the answer. For example, the key success factors of the Acer Group, based in Taiwan, one of the most renowned, largest computer manufacturing groups in the world and famous for its "faster-food business model" (i.e. assembly into a computer just before purchase) (Mathews and Snow, 1998), belong to the logistics domain.

Unfortunately, empirical studies have rarely focused on logistics management in Taiwan but have concentrated on logistics management in Western developed countries (Luo et al., 2001), displaying a bias towards the USA. Moreover, even though many researchers may have demonstrated that variant logistics capabilities and competencies are positively associated with 
logistics and/or financial performance (Stank and Lackey, 1997; Bowersox et al., 1999; Zhao, 2001; Fawcett and Cooper, 1998; Rogers et al., 1996; Narasimhan and Kim, 2001), there is still insufficient evidence to conclude that logistics practices in a huge geographic area such as America have exactly the same effect in a smaller geographic area such as Taiwan.

Many conceptualisations and developments in logistics have been borrowed from other disciplines (Stock, 1990). It may now be considered a mature science but only in the initial substantive justification research stages (Mentzer and Kahn, 1995). Garver and Mentzer (1999: 33) commented that 'as the discipline matures, rigorous research methods and techniques should become the standard for developing and testing logistics theory'. It is thus time for the logistics discipline to shift towards greater hypothesis testing, more rigorous data analysis and measurement of validity or reliability (Mentzer and Kahn, 1995).

In this regard, structural equation modelling is a rigorous and powerful statistical research technique, which can easily assess validity and reliability (Gerbing and Anderson, 1988) and rigorously test the hypotheses (Koufteros, 1999; Lin et al., 2005). Accordingly, Garver and Mentzer stated (1999:33), 'Given the importance of testing for validity when conducting rigorous theoretical research, logistics research needs to more fully utilise this [structural equation modelling] methodological tool'. Consequently, in the present study, structural equation modelling will be the main data analysis method applied in the practical analysis.

The current study empirically investigates proposed theoretically-based relationships between logistics competency, logistics performance, and financial performance. In the following section, the existing literature is reviewed to provide a theoretical basis for proposing comprehensive hypotheses and establishing the research structure. Next, the research methodology is described and the collected data are examined using structural equation modelling (SEM) to ascertain whether they have been appropriately analysed. The results of the statistical analysis are detailed in the following section, while the final section concludes the findings of this study. The implications and limitations of the study are also presented.

\section{Literature review}

\subsection{Logistics competencies}

Researchers adopted several different typologies as presented in Table 1 to identify logistics competencies or capabilities. 
Table 1

Typology of logistics competencies and capabilities

\begin{tabular}{|c|c|c|}
\hline Author(s) & $\begin{array}{l}\text { Capabilities or } \\
\text { Competencies }\end{array}$ & Sub-dimension of Capabilities or Competencies \\
\hline $\begin{array}{l}\text { Bower and Hout } \\
\text { (1992); Daugherty } \\
\text { and Pittman (1995) }\end{array}$ & Fast cycle & \\
\hline \multirow{4}{*}{$\begin{array}{l}\text { MSUGLRT(1995); } \\
\text { Bowersox, Closs and } \\
\text { Stank (1999); } \\
\text { Goldsby and Stank } \\
\text { (2000) }\end{array}$} & Positioning & Strategy, Supply chain, Network, Organisation \\
\hline & Integration & $\begin{array}{l}\text { Supply chain unification, Information technology, Information } \\
\text { sharing, connectivity, standardisation, Simplification, Discipline }\end{array}$ \\
\hline & Agility & Relevancy, Flexibility, Accommodation \\
\hline & Measurement & Functional Assessment, Process Assessment, Benchmarking \\
\hline $\begin{array}{l}\text { Fawcett, Calantone, } \\
\text { and Smith(1996) }\end{array}$ & Flexibility & $\begin{array}{l}\text { Manufacturing flexibility } \\
\text { Logistics flexibility }\end{array}$ \\
\hline $\begin{array}{l}\text { Fawcett, Stanley, and } \\
\text { Smith (1997b) }\end{array}$ & $\begin{array}{l}\text { Delivery, Quality, } \\
\text { Flexibility, Cost, and } \\
\text { Innovation }\end{array}$ & \\
\hline \multirow{2}{*}{$\begin{array}{l}\text { Morash, Dröge, and } \\
\text { Vickery, (1996a) }\end{array}$} & $\begin{array}{l}\text { Demand-Management } \\
\text { Interface }\end{array}$ & $\begin{array}{l}\text { Customer service } \\
\text { Logistics quality }\end{array}$ \\
\hline & $\begin{array}{l}\text { Supply-Management } \\
\text { Interface }\end{array}$ & $\begin{array}{l}\text { Channel distribution } \\
\text { Total cost minimisation }\end{array}$ \\
\hline \multirow{2}{*}{$\begin{array}{l}\text { Morash, Dröge, and } \\
\text { Vickery (1996b) }\end{array}$} & Demand-Oriented & $\begin{array}{l}\text { Pre-sale customer service, Post-sale customer service, Delivery } \\
\text { speed, Delivery reliability, Responsiveness to target market(s) }\end{array}$ \\
\hline & Supply-Oriented & $\begin{array}{l}\text { Widespread distribution coverage (availability), Selective } \\
\text { distribution coverage, Low total cost distribution }\end{array}$ \\
\hline $\begin{array}{l}\text { Morash and Clinton } \\
\text { (1997) }\end{array}$ & Transportation & $\begin{array}{l}\text { Time compression, Reliability, Standardisation, JIT delivery, } \\
\text { Information systems support, Flexibility, customisation }\end{array}$ \\
\hline \multirow{4}{*}{$\begin{array}{l}\text { Stank and Lackey } \\
\text { (1997) }\end{array}$} & Position & $\begin{array}{l}\text { Customer focus, Organisational control, Organisational } \\
\text { implementation }\end{array}$ \\
\hline & Integration & $\begin{array}{l}\text { Connectivity, Functional integration, Information sharing, } \\
\text { Information technology, Supplier relations }\end{array}$ \\
\hline & Agility & Operational flexibility, Personnel flexibility \\
\hline & Measurement & Activity-based costing, Benchmarking, Performance assessment \\
\hline \multirow{4}{*}{$\begin{array}{l}\text { Bowersox, Closs and } \\
\text { Stank (1999) }\end{array}$} & Customer Integration & Segmental focus, Relevancy, Responsiveness, Flexibility. \\
\hline & Internal Integration & $\begin{array}{l}\text { Cross-functional unification, Standardisation, Simplification, } \\
\text { Compliance, Structural adaptation }\end{array}$ \\
\hline & $\begin{array}{l}\text { Material/Service Supplier } \\
\text { Integration }\end{array}$ & $\begin{array}{l}\text { Strategic alignment, Operational fusion, Financial linkage, } \\
\text { Supplier management }\end{array}$ \\
\hline & Technology and Planning & $\begin{array}{l}\text { Information management, Internal communication, connectivity, } \\
\text { collaborative forecasting and planning }\end{array}$ \\
\hline
\end{tabular}




\begin{tabular}{l|l|l}
\hline & Measurement Integration & $\begin{array}{l}\text { Functional assessment, Activity based and total cost } \\
\text { methodology, Comprehensive metrics, Financial impact }\end{array}$ \\
\cline { 2 - 3 } & Relationship Integration & $\begin{array}{l}\text { Role specificity, Guidelines, Information Sharing, Gain/Risk } \\
\text { sharing }\end{array}$ \\
\hline \multirow{2}{*}{$\begin{array}{l}\text { Gilmour } \\
\text { (1999) }\end{array}$} & Process & $\begin{array}{l}\text { Customer-driven supply chain, Efficient logistics, Demand- } \\
\text { driven sales planning, Lean manufacturing, Supplier partnering, } \\
\text { Integrated supply chain management. }\end{array}$ \\
\cline { 2 - 3 } & Information Technology & $\begin{array}{l}\text { Integrated information systems } \\
\text { Advanced technology }\end{array}$ \\
\cline { 2 - 3 } $\begin{array}{l}\text { Fawcett, Calantone } \\
\text { and Roath(2000) }\end{array}$ & Organisation & $\begin{array}{l}\text { Integrated performance measurement, Teamwork, Aligned } \\
\text { organisation structure }\end{array}$ \\
\cline { 2 - 3 } & Cost & $\begin{array}{l}\text { Logistics quality } \\
\text { Manufacturing quality }\end{array}$ \\
\hline Lynch, Keller and \\
Ozment(2000) & Process & $\begin{array}{l}\text { Logistics cost } \\
\text { Manufacturing cost }\end{array}$ \\
\hline Zhao, Dröge and & Customer-added Service & Segmental focus, Relevancy, Responsiveness, Flexibility. \\
\hline Stank(2001) & Information-Focused & Information sharing, Information technology, connectivity. \\
\hline Lloréns et al.(2005) & Manufacturing flexibility & Process, Product, Routine, Volume, Expansion flexibility \\
\hline Lin et al.(2006) & Agility & Responsiveness, Competency, Flexibility, and Quickness \\
\hline Sorce Sum &
\end{tabular}

Source: Summarised from the literature and tabled by the Authors.

Bower and Hout (1992) and Daugherty and Pittman (1995) concentrated on fast cycle capabilities and indicated how firms can utilise time-based strategies to acquire competitive advantage. Fawcett et al. (1996, 2000) employed cross-function research (i.e. logistics and manufacturing) and concluded that flexibility, quality, and cost are important capabilities that help firms enhance their performance and manage worldwide resources and markets. Morash et al. (1996a, 1996b) explored logistics capabilities conducting cross-function research (i.e. production, logistics, marketing, and new product development) and sole-function research (i.e. logistics) on 65 furniture manufacturing firms. The former (Morash et al., 1996a) concluded that excellence solely in one functional area is not the source of competitive advantage. Rather, boundary-spanning interface capabilities, including demand management and supply management interface capabilities, across functional areas become a source of supply chain advantage (SCA). In contrast, the latter (Morash et al., 1996b) identified logistics capabilities as demand-oriented and supplyoriented capabilities and concluded that some (i.e. delivery speed, reliability, responsiveness, and low cost distribution) were sources of SCA. Gilmour (1999) undertook a cross-national study of Australia, Japan, South Korea and Taiwan, exploring and identifying supply chain capabilities, including process, technology, and organisation capabilities. Morash and Clinton (1997) concluded that transportation capabilities may play a lead role in the integration and coordination of supply 
chain flow.

A comprehensive examination of logistics capabilities was performed by MSUGLRT (1995) and later extended by Bowersox et al. (1999). MSUGLRT (1995) identified 17 logistics capabilities included in four logistics competencies. Bowersox et al. (1999) further expanded the 17 logistics capabilities to 25 supply chain capabilities related to 6 supply chain competencies and confirmed that the capabilities were critical to firms' success. Following on from this work, Stank and Lackey (1997) examined capabilities related to competence and found integration and agility to be of particular importance to logistical performance. Lynch et al. (2000) combined industrial organisation economics and resource-based theory to explore the relationship between logistics capabilities, generic business strategies, and performance. They identified two logistics capabilities (process capabilities and value-added service capabilities) and concluded that logistics capabilities are associated with strategy and need to be combined in order to achieve superior firm performance. Goldsby and Stank (2000) later confirmed the positive relationship between 17 logistics capabilities, and the implementation of environmentally responsible logistics. More, recently, Zhao et al. (2001) found that customer-focused capabilities directly affect performance. In contrast, information-focused capabilities indirectly affect performance.

In this study logistics competency, including customer focused logistics competency, integration and knowledge competency, agility competency, and measurement competency, can be viewed as sources of sustained competitive advantage (Fawcett and Clinton, 1996; Stank et al., 1997; Innis and La Londe, 1994; Kanji and Wong, 1999; Whitehill, 1997; Lau and Hurley, 2001; Bowersox et al., 1992; Byrne and Markham, 1991) and they are explained as follows:

\subsection{Customer focused logistics competency}

Traditional logistics strategy always chooses to seek a balance between quality service and reasonable operating cost, but "leading-edge" and "world class" logistics firms are "willing to invest in capital and operating expense to achieve superior customer service' (MSUGLRT, 1995: 67) in order to meet customer expectations (Stock and Lambert, 1992). Thus, customer focused logistics competency (also called tailored logistics or logistically distinct businesses) becomes the next governing element of strategy (Fuller, 1993; Stank and Lackey, 1997). Customer focused logistics strategy stresses tailored logistics services to generate maximum customer satisfaction, market share, or performance, or to achieve business excellence (Fawcett and Clinton, 1996; Stank et al., 1997; Innis and La Londe, 1994; Kanji and Wong, 1999).

\subsection{Integration and knowledge competency}

Integration may be the most important issue in logistics and SCM because '[ $\mathrm{t}]$ he most fundamental shift in logistics thinking is to view functional excellence in terms of performance that enhances overall supply chain integration' (Bowersox et al., 1999: 19). 'The concept of integration within a business and between businesses is not new, but the acceptance of its validity by managers is' (Christopher, 1998). Notably, the Dell computer company's virtual integration, blurring traditional boundaries and roles in the value chain, may become a new organisational model in the 
new information generation (Magretta, 1998).

Researchers have focused their studies on the functional integration between logistics and the marketing department (e.g. Rinehart et al., 1989; Murphy and Poist, 1996), IT department (e.g. Kent, 1996), or other departments (e.g. Kahn and Mentzer, 1996; Morash et al., 1996a). In addition, integration has been extended from a single firm to the overall supply chain level, including basic supply chain integration (that is, boundary-spanning linkages with customers or suppliers) and advanced supply integration (that is, coordination of multiple enterprises in long-term relationships) (Bowersox, 1997). Furthermore, Dornier et al. (1998) contended that integration must be extended to lose geographical boundaries, and thus proposed three types of integration, namely, geographical, sectoral, and functional integration, as the key drivers for a new global logistics approach. Integration is therefore identified as 'the degree to which logistics tasks and activities within the firm and [a] cross the supply chain are managed in a coordinated fashion' (Chow et al., 1995: 291).

In addition, knowledge management has become important for supply chain advantage (SCA) (Whitehill, 1997). Design knowledge intensity is positively associated with financial performance (Germain et al., 2001). Ernst (2000) indicated that the most critical factor affecting the ability of small Taiwanese firms to compete in the computer industry is cross-organisational coordination of knowledge creation.

\subsection{Agility}

An agility competency has replaced delivery speed (1990s), quality (1980s), or cost (1970s) to become the main competitive priority in the twenty-first century (Greis and Kasarda, 1997). Creating agile supply chains has become a source of competitive advantage (Lau and Hurley, 2001). Most studies have viewed agility as a general management or a strongly manufacturing biased concept (Yusuf et al., 1999; Gunasekaran, 1999; Zhang and Sharifi, 2000) and have not focused on the concept in the "supply chain as a whole" (Christopher, 2000).

\subsection{Measurement}

As the adage says "if you cannot measure it, you cannot manage it," thus high-performance logistics 'requires mastering the discipline of measurement' (Keebler et al., 1999: 2), especially in the environment of supply chain vs. supply chain (Fawcett and Cooper, 1998). Comprehensive performance measurement has been adopted by leading edge (Bowersox et al., 1989), logistics excellence (Bowersox et al., 1992; Byrne and Markham, 1991), best practice (Boyson et al., 1999), and world-class firms (MSUGLRT, 1995) in the logistics and SCM field.

Measurement refers to a firm's performance measurement system (Novack et al., 1994) which plays an important role in managing the business because 'it provides the information necessary for decision making and actions' (Holmberg, 2000: 848). Keebler et al. (1999) indicated that an excellent measurement system should produce three primary benefits namely reduced costs, improved service, and the generation of healthy growth. Fawcett and Cooper (1998) asserted that new information systems can facilitate measurement.

Measurement is not solely a logistics and supply chain problem, but is particularly critical in 
the logistics and SCM field because of cross-functional and inter-organisational requirement (Bowersox et al., 1999; Gunasekaran, 2001; Holmberg, 2000). Recent research has identified performance measurement as one of the top three areas of logistics research needs (Bowersox and Closs, 1996).

\subsection{Performance}

Performance has been viewed in a great variety of ways by logistics researchers (Chow et al., 1994; 1995; Bowersox et al., 1999; PRTM consulting, 1994). The definition and measurement of performance is often a challenge for researchers because organisations have multiple and frequently conflicting goals (Chow et al., 1994; Rogers et al., 1996) Thus, the definition of the performance is 'ultimately up to the evaluator' (Haytko, 1994: 263).

Performance measures can be classified into outcome-based performance (the final outcomes of a set of behaviours) and behaviour-based performance (the set of behaviours that precede the final outcome) (Haytko, 1994). In a channel of distribution, outcome-based performance measures focus on a channel member's results, that is, financial measures of performance or channel member satisfaction. In contrast, behaviour-based performance focuses on the specific activities of a channel member such as stocking, warehousing, delivering, and promoting goods (Rogers et al., 1996; Maltz, A. and Maltz, E., 1998). Outcome-based measures are more frequently used in empirical studies but it has been argued that they measure only past success or failure, and do not explain why the one or the other occurred nor what can be done in the future (Haytko, 1994; Spriggs, 1994). However, behaviour-based measures can provide supplemental information (Roger et al., 1996; Stank and Lackey, 1997). Therefore, in channel member performance measurement Haytko (1994) recommends a multiple indicators approach that includes both outcome-based and behaviour-based performance.

Performance per se can be measured in two ways: hard (objective) performance and soft (perceptual or responsiveness) performance (Dalton et al., 1980; Chow et al., 1994; Maltz, A. and Maltz, E., 1998). Hard performance measures include raw financial statistics, cost statistics, commissions, and services rendered, whereas soft performance indicators involve supervisor appraisals and self-perceptions.

Additionally, performance can be classified as financial performance, which reflects 'the fulfilment of the economic goals of the firm', and operational performance, which reflects key operational success factors that might lead to financial performance (Venkatraman and Ramanujam, 1986: 803-804).

Performance in this study is separated into financial performance and operational (i.e. logistics) performance. All performance indexes are measured according to soft or perceptual performance and outcome-based measurement is according to management's perceptions of a firm's performance compared to that of major competitors, because actual (hard) performance data related to an individual or strategic business unit's competitive position is not generally published in annual reports and is usually closely guarded and therefore very difficult to obtain (Fawcett et al. 1996). Moreover, this study undertakes cross-industry research, and objective performance lacks consensus regarding a valid cross-industry measure of performance (Tan et al., 1999). However, 
recent research has found that certain perceptual measures correlate closely with objective performance and are therefore acceptable and useful substitutes when objective data are unavailable (Dess and Robinson, 1984; Vickery et al., 1993; Fawcett et al., 1996, 1997a). Financial performance (FP) includes profit, ROA, and ROI. Logistics performance (LP) includes delivery dependability, order fill capacity, responsiveness to key customer, advanced notification, customer service flexibility, and product introduction.

\section{The research framework and hypotheses}

This study mainly assumes that logistics is a kind of special competency which, if acquired, may enhance sustained competitive advantage. The relationship between manufacturing firms' logistics competency and logistics and financial performance will be explored as shown in Figure 1. The relationships will be examined by structural equation modelling (SEM) and the analysis will attempt to determine whether logistics competency is important for enhancing logistics or financial performance.

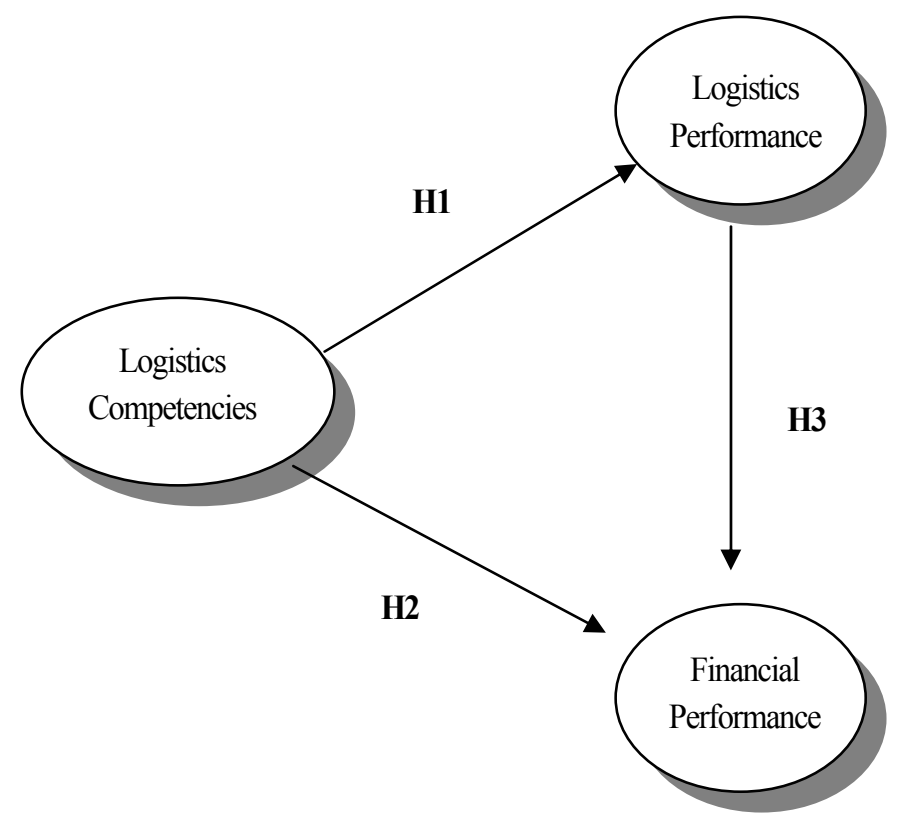

Figure 1. Basic research framework

Empirical studies have demonstrated a positive association between logistics competency and logistics performance (Stank and Lackey, 1997) and financial performance (Morash et al., 1996; Fawcett et al, 2000; Źhao et al, 2001). Thus, this paper hypothesises that: 
- H1: In Taiwan's manufacturing firms, there is a positive association between logistics competency and logistics performance.

- H2: In Taiwan's manufacturing firms, there is a positive association between logistics competency and financial performance.

Moreover, Venkatraman and Ramanujam's (1986) suggestion, that operational performance (such as logistics performance) reflects key operational success factors that might lead to financial performance, has been demonstrated by Ellinger et al. (2000). Thus, logistics performance can affect financial performance. In other words, logistics performance mediates the relationship between logistics capabilities/competencies and financial performance. Consequently, the present research further hypothesises that:

- H3: In Taiwan's manufacturing firms, there is a positive association between logistics performance and financial performance.

\section{Methodology}

\subsection{Measures}

Financial and logistics performances were measured using a 9-item performance scale (p1p9) which had been employed in previous logistics literature (Tracey, 1998; Bowersox et al., 1999; Vickery et al., 1999, Tan et al., 1999, Ellinger et al., 2000, Lynch et al., 2000, Germain et al., 2001, Źhao et al., 2001) as shown in Table 2. Respondents were asked to provide a rating (Likert 7-point scales) of the SBU (i.e. strategy business unit) or firm's performance relative to its major competitors for each item, where 1 represented "Much Worse" and 7 represented "Much Better".

Table 2

Performance scale and operational definition

\begin{tabular}{c|cl}
\hline Item & \multicolumn{1}{|c}{ Title } & Operational Definition \\
\hline \hline \multicolumn{2}{c}{ Financial Performance } & \\
\hline p1 & Profit & Profit (before tax) \\
\hline p2 & ROA & The ratio of income before interest expense divided by average total asset. \\
\hline p3 & ROI & The ratio of income before interest expense divided by capital employed. \\
\hline Logistics Performance & \\
\hline p4 & Delivery Dependability & To meet quoted or anticipated delivery dates and quantities on a consistent basis. \\
\hline p5 & Order fill capacity & To provide desired quantities on a consistent basis. \\
\hline p6 & $\begin{array}{c}\text { Responsiveness to key } \\
\text { customer }\end{array}$ & To respond to the needs and wants of key customers. \\
\hline p7 & Advanced notification & To notify customers in advance of delivery delays or product shortages. \\
\hline
\end{tabular}




\begin{tabular}{c|c|l}
\hline p8 & Customer service flexibility & To accommodate special customer service requests. \\
\hline p9 & Product Introduction & To accommodate new product introductions (rollouts to market). \\
\hline
\end{tabular}

Source: Tabled by the Authors

In contrast, logistics competency was measured using a 24-item scale (R1-R24) originally developed by MSUGLRT (1995), and further developed by Stank and Lackey (1997) and Keebler et al. (1999), as shown in Table 3. Several researchers had recommended the use of the scale in empirical studies (e.g. Goldsby and Stank, 2000; Bowersox, et al., 1999; Stank and Lackey, 1997). Seven-point Likert-type scale anchors were also used. Respondents were asked to indicate their level of agreement with each item, where 1 represented "Strongly Disagree" and 7 represented "Strongly Agree".

\section{Table 3}

Items and latent variables

\begin{tabular}{|c|c|c|}
\hline Items and Latent variables & Mean & SD \\
\hline 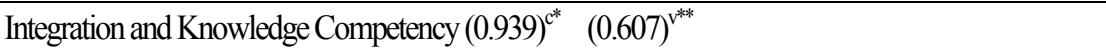 & $4.77 * * *$ & 1.00 \\
\hline $\begin{array}{l}\text { R1. My firm successfully utilises time-based logistics solutions like continuous replenishment, } \\
\text { quick response and Just-in-Time with customers and/or suppliers. }\end{array}$ & 4.69 & 1.23 \\
\hline $\begin{array}{l}\text { R2. My firm has active programmes to capture the experience and expertise of individuals and } \\
\text { transfer this knowledge throughout the organization. }\end{array}$ & 4.86 & 1.10 \\
\hline $\begin{array}{l}\text { R3. My firm successfully integrates operations with customers and/or suppliers by developing } \\
\text { interlocking programmes and activities. }\end{array}$ & 4.74 & 1.08 \\
\hline R4. My firm clearly defines roles and responsibilities with our supply chain partners. & 4.94 & 1.16 \\
\hline $\begin{array}{l}\text { R5. Logistics information systems in my firm are being expanded to include more integrated } \\
\text { applications. }\end{array}$ & 4.45 & 1.32 \\
\hline R6. The information available in my firm is accurate, timely and formatted to facilitate use. & 4.98 & 1.12 \\
\hline R7. My firm effectively shares operational information between departments. & 4.89 & 1.11 \\
\hline $\begin{array}{l}\text { R8. My firm has adequate ability to share both standardised and customised information externally } \\
\text { with suppliers and/or customers. }\end{array}$ & 4.56 & 1.25 \\
\hline R9. My firm has active programmes to enforce standardised logistical performance. & 4.81 & 1.21 \\
\hline R10. My firm regularly achieves stated logistical performance goals. & 4.86 & 1.18 \\
\hline Customer Focused Competency $(0.737)^{\mathrm{c}}(0.585)^{\mathrm{v}}$ & 5.41 & 0.79 \\
\hline R11. Customer requirements are regularly employed in planning. & 5.28 & 0.91 \\
\hline $\begin{array}{l}\text { R12 Processes are in place that ensure customer feedback and complaint-driven improvements get } \\
\text { corrective action and appropriate priority. }\end{array}$ & 5.55 & 0.88 \\
\hline Agility Competency $(0.889)^{\mathrm{c}}(0.665)^{\mathrm{v}}$ & 4.78 & 0.94 \\
\hline $\begin{array}{l}\text { R13. My firm has a flexible programme of special services that can be matched to changing } \\
\text { customer requirements. }\end{array}$ & 4.87 & 1.17 \\
\hline R14. My firm has a predetermined authorisation programme to accommodate special requests of & 4.93 & 1.17 \\
\hline
\end{tabular}




\begin{tabular}{|c|c|c|}
\hline selected customers. & & \\
\hline $\begin{array}{l}\text { R15. My firm is able to accommodate unique customer requests by implementing pre-planned } \\
\text { solutions. }\end{array}$ & 4.74 & 1.13 \\
\hline $\begin{array}{l}\text { R16. My firm has been able to reduce reliance on forecasting by sharing information with } \\
\text { customers. }\end{array}$ & 4.54 & 1.20 \\
\hline Measurement Competency $(0.944)^{\mathrm{c}} \quad(0.680)^{\mathrm{v}}$ & 4.92 & 0.92 \\
\hline $\begin{array}{l}\text { R17. The number of internal performance measures regularly used by my firm has increased over } \\
\text { the past three years. }\end{array}$ & 5.13 & 1.09 \\
\hline $\begin{array}{l}\text { R18. My firm extensively measures logistics performance in terms of cost, productivity, customer } \\
\text { service, asset management and quality. }\end{array}$ & 5.34 & 1.06 \\
\hline R19. My firm benchmarks performance metrics. & 5.23 & 1.17 \\
\hline R20. The logistics measures my firm uses accurately capture the events/activities being measured. & 4.71 & 1.16 \\
\hline R21. The logistics measures my firm uses are interpreted similarly by internal users. & 4.67 & 1.18 \\
\hline $\begin{array}{l}\text { R22. The logistics measures my firm uses internally have significant benefits that outweigh the } \\
\text { costs of data collection, analysis, and reporting. }\end{array}$ & 4.61 & 1.19 \\
\hline R23. The logistics measures my firm uses are readily understandable by decision-makers & 4.60 & 1.11 \\
\hline $\mathrm{R} 24$. The logistics measures my firm uses promote coordination across functions and divisions & 5.05 & 1.14 \\
\hline Financial Performance $(0.952)^{\mathrm{c}} \quad(0.867)^{\mathrm{v}}$ & 4.55 & 1.24 \\
\hline p1. Profit(before tax). & 4.61 & 1.39 \\
\hline p2. Return on assets (ROA) & 4.57 & 1.30 \\
\hline p3. Return on investment (ROI) & 4.54 & 1.30 \\
\hline Logistics Performance $(0.907)^{\mathrm{c}} \quad(0.660)^{\mathrm{v}}$ & 5.10 & 0.91 \\
\hline p4. To meet quoted or anticipated delivery dates and quantities on a consistent basis & 5.01 & 1.10 \\
\hline p5. To provide desired quantities on a consistent basis & 5.22 & 1.09 \\
\hline p6. To respond to the needs and wants of key customers. & 5.30 & 1.02 \\
\hline p7. To notify customers in advance of delivery delays or product shortages. & 5.00 & 1.03 \\
\hline p9. To accommodate new product Introductions (rollouts to market) & 5.02 & 1.10 \\
\hline
\end{tabular}

\subsection{Sample}

The hypotheses were tested on 1,200 of the largest manufacturing firms in Taiwan drawn from the annual report, entitled "The Top 5000: the Largest Corporations in the Republic of China" (China Credit Information Service Company) (2000). Company presidents or chief executive officers were considered appropriate questionnaire respondents to provide information. In order to improve the response rate, several methods were employed, such as follow-up mailings, stamps on return envelopes, assurance of anonymity, university sponsorship, and use of coloured questionnaires (Babble, 1998; Saunders et al., 2000; Weisberg et al., 1996). The total response rate was 16.5 per cent (198/1200). To detect any potential non-response bias, the second wave of respondents' responses was assumed to be most similar to non-respondents' (Lambert and Harrington, 1990). No statistical evidence of non-response bias (at $\mathrm{p}<0.05$ ) was found. 


\subsection{The profile of the respondents}

The top six industries sampled were the electronics industry: 35 (17.7\%) firms; the semiconductor industry: 20 (10.1\%) firms; the information and communications industry: 19 (9.6\%) firms; the chemical product industry: $18(9.1 \%)$ firms; the automotive and accessories industry: 18 (9.1\%); and the metal refinery industry: 18 (9.1\%). The eleven industries surveyed demonstrated no significant difference in the four logistics competencies, logistics performance, and financial performance applying the Kruskal-Wallis test. This implies that industry difference is not the key factor influencing logistics competencies, logistics performance, and financial performance.

Nineteen per cent of sampled firms had over 1,000 employees, whereas $25 \%$ of sampled firms had fewer than 200 employees. Most sampled firms employed between 200 - 400 (30\%) full-time workers. The majority of respondents $(73 \%)$ had worked in their present firms for over 4 years and consequently had sufficient knowledge to answer the questionnaire accurately and reliably. In addition, $80 \%$ of questionnaires were completed by vice-presidents or presidents $(19 \%)$, department and senior managers (37\%), presidents' assistants (11\%), and junior managers (13\%), which further reinforced the reliability of the survey's findings. Table 4 summarises the characteristics of the respondents and their companies.

Table 4

Characteristics of respondents

\begin{tabular}{l|c|c|c}
\hline \multicolumn{2}{c}{ Industry Description- Leading Categories } & \multicolumn{2}{c}{ Respondents' Position } \\
\hline \hline Electronic & $17.7 \%$ & Vice-president or above & $17.1 \%$ \\
Semi-Conductor & $10.1 \%$ & Department/ Area manager & $21.7 \%$ \\
Information \& Communication & $9.6 \%$ & Senior manager & $11.6 \%$ \\
Chemical Product & $9.1 \%$ & President assistant & $10.1 \%$ \\
Automotive \& Accessories & $9.1 \%$ & Junior manager & $12.1 \%$ \\
Metal Refinery & $9.1 \%$ & Other & $18.7 \%$ \\
Other $^{\text {b }}$ & $35.3 \%$ & N.A. ${ }^{\text {a }}$ & $8.1 \%$ \\
\hline Employees & & Sales (Hundred Million New Taiwanese Dollars) \\
\hline$<100$ & $4 \%$ & $<10$ & $13.1 \%$ \\
$101-200$ & $21.2 \%$ & $11-2-$ & $29.3 \%$ \\
$201-400$ & $28.8 \%$ & $21-30$ & $12.1 \%$ \\
$401-600$ & $12.1 \%$ & $31-40$ & $12.1 \%$ \\
$601-1000$ & $14.1 \%$ & $41-100$ & $19.2 \%$ \\
$>1001$ & $18.6 \%$ & $>101$ & $12.6 \%$ \\
N.A. ${ }^{\text {a }}$ & $1 \%$ & N.A & $1 \%$ \\
\hline Length of Service in theCompany & & & \\
\hline$<3$ & $26.3 \%$ & & \\
$4-6$ & $19.7 \%$ & & \\
$7-9$ & $10.6 \%$ & & \\
\hline
\end{tabular}




\begin{tabular}{l|c|l|l}
\hline $10-12$ & $10.1 \%$ & & \\
$13-15$ & $7.1 \%$ & & \\
$>15$ & $22.2 \%$ & & \\
N.A. & $4 \%$ & & \\
\hline
\end{tabular}

Notes: ${ }^{\mathrm{a}}$ N.A. represents no response. ${ }^{\mathrm{b}}$ Other industries include metal work, textiles, chemicals, paper, rubber, plastic, machineries, pharmaceutical, and so forth. No industry represented more than $6 \%$ of the total sample

\subsection{Data screening}

The regression substitution approach, which simply replaces the unobserved score by regression imputation, is used for remedying missing data (Hair et al., 1998). In addition, Roth (1994) suggested that regression substitution is an adequate method when the amount of missing data is less than $10 \%$. In this study, missing data existed but the amount of missing data in respect of each variable was small (less than 6.6\%) and, accordingly, the regression substitution approach was used to remedy this and the sample size was kept at the original size (i.e. 198). Multivariate outliers were identified using the Mahalanobis d-squared measure. However, they were retained because there was insufficient proof to demonstrate that they were not representative of the sampling population (Kline, 1998). Linearity was also demonstrated by all pairwise scatterplots randomly selected (Tabachnick and Fidell, 1996). Although nonnormality was predicted because the 198 respondents were drawn from the 1,200 largest manufacturing companies in Taiwan, it had still to be demonstrated by a series of multi-method tests. Results of the skewness and kurtosis for part variables, the Kolmogorov-Smirnov test for all variables, and the multivariate kurtosis were significant, implying that the assumption of multivariate normality was violated (Hair et al., 1998). Accordingly, the bootstrapping approach (Nevitt and Hancock 2001) was employed for remedying nonnormality, because some nonnormality variables were difficult to transform.

\section{Analysis and results}

The two-step SEM approach was adopted (Anderson and Gerbing, 1988). The authors firstly assessed the validity of the measurement model by confirmatory factor analysis (CFA) and then, when the measurement model had been validated, proceeded to the second step, estimating the structural model between latent variables. AMOS (Arbuckle, 1997) and Maximum Likelihood (ML) estimation was used to deal with the CFA analysis and full structural equation models. The sample size was 198, an adequate sample size for use with the SEM technique (Hair et al., 1998).

\subsection{Using CFA to assess validity and reliability}

In logistics research, validity is very important, because it is the basis of the logistics research process (Garver and Mentzer, 1999). It can, however, be examined from many different 
perspectives (Dunn et al., 1994; Scandura and Williams, 2000). In this study, the following types of validity and reliability were identified, elaborated and assessed: (1) unidimensionality, (2) reliability, (3) convergent validity, and (4) discriminant validity.

The minimum requirements for model identification in the measurement model of CFA were satisfied. Bootstrap samples were also successful. In addition, the Bollen-Stine procedure was correct (Byrne 2001). Unidimensionality and convergent validity were satisfactory (Garver and Mentzer, 1999; Koufteros, 1999) because (1) the three goodness-of-fit indexes (CFI=0.924>0.90; $\mathrm{TLI}=0.916>0.90 ; \mathrm{RMSEA}=0.068<0.08$ ) satisfied the cut-off criteria, (2) no pair of standardised residual values was greater than \pm 2.58 , (3) no specifically larger modification indices (MI) values were expected to be modified, (4) all expected parameter change (EPC) values were smaller than \pm 0.3 , (5) all t-values of variables were significant (t-values $> \pm 1.96$ ), and (6) all factor loadings $(\lambda)$ on each variable were greater than 0.7 .

Reliability was assessed by construct reliability and variance extracted. Both construct reliability and variance extracted were verified because all construct reliability values were greater than 0.7, and all values of variance extracted were greater than 0.5 (Garver and Mentzer, 1999). In addition, discriminant validity, which was assessed using the $\chi_{\text {different }}^{2}$ test to compare the base model (unconstrained) and other pairs of constructs (constrained) (Anderson and Gerbing, 1988), was also satisfactory because all pairs of latent variables were statistically significant $(p<0.05)$. Items and latent variables are shown in Table 3. After CFA, the four logistics competencies, (including customer focused logistics competency, integration and knowledge competency, agility competency, and measurement competency) and two performance indices, (including, logistics performance and financial performance) were identified

Because the validity and reliability of four logistics competencies indexes were verified, the summated scale, which is formed by combining several individual variables into a single composite measure, was adopted in this research (Hair et al., 1998) for subsequent analysis.

\subsection{Using SEM to test the full structural model}

The minimum requirements for full structural model identification of SEM were satisfied as shown in Figure 2. Bootstrap samples were also successful (chi-square $=128.396$; $\mathrm{df}=62$; $\mathrm{p}=0.000$ ). The fit indexes were accepted (CFI $=0.967$; TLI $=0.959 ; \mathrm{RMSEA}=0.074)$, implying that this estimated model was a good-fit model.

Standardised residuals and the modification index were examined after evaluation of fit. No variables in this model had to be modified because none had sizeable standardised residuals (value $> \pm 2.58$ ), nor especially larger MI and EPC values .

\section{Research results}

Of the three causal paths in the hypothesised model, only the two hypothesised paths (H1: Logistics competency $\rightarrow$ LP; H3: LP $\rightarrow$ FP) were found to be statistically significant $(\lambda=0.734$ 
$\mathrm{t}=9.718$ and $\lambda=0.851 \mathrm{t}=6.508$, respectively). The $\mathrm{H} 2$ hypothesised paths (Logistics competency $\rightarrow$ $\mathrm{FP}$ ) were not significant. Thus, $\mathrm{H} 1$ and $\mathrm{H} 3$ were supported, $\mathrm{H} 2$ was not supported; these results are shown in Figure 2.

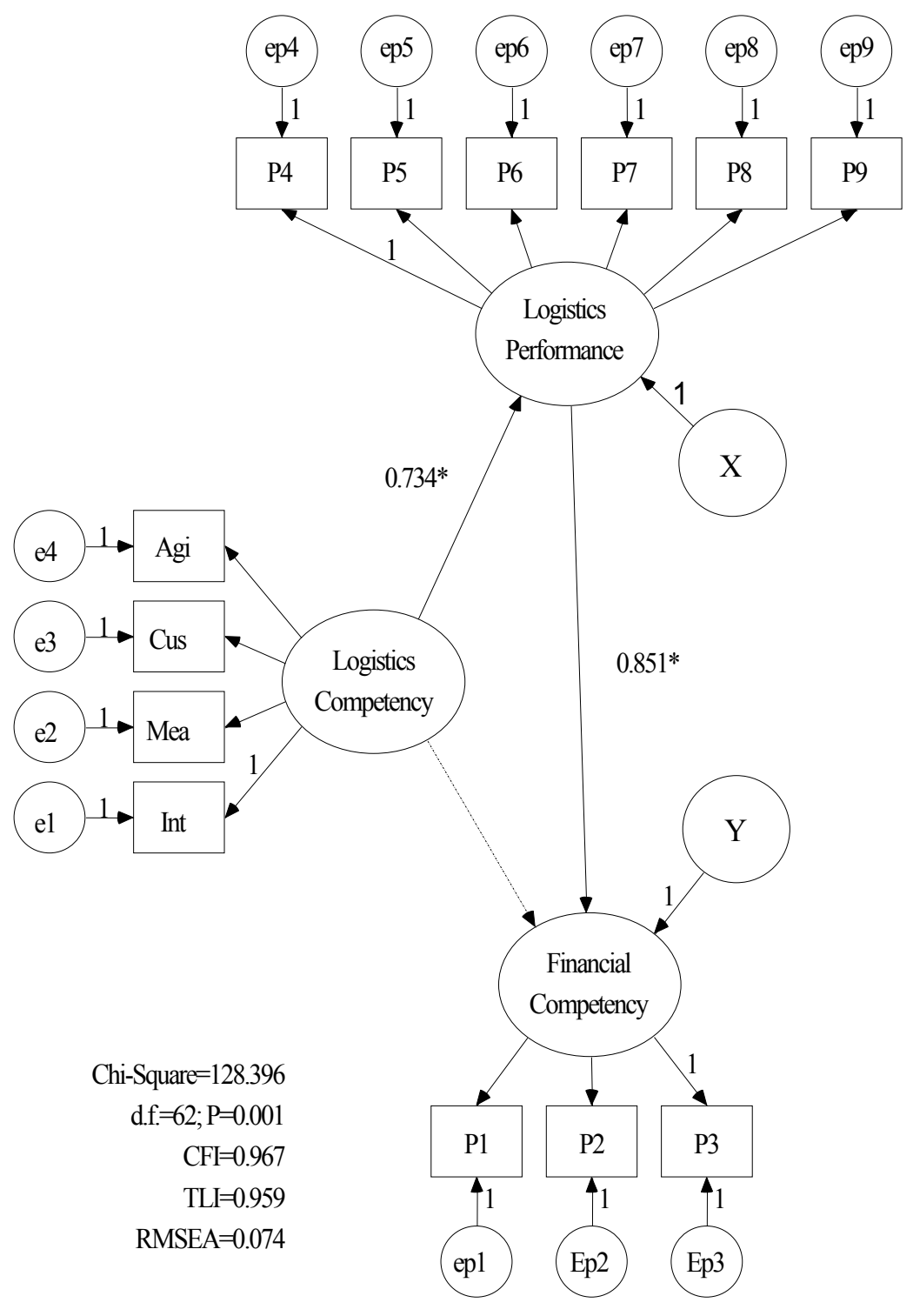

Notes: 1. Broken lines indicate no significant relationship. ${ }^{*} \mathrm{p}<0.05$

2. Agi=Agility Competency; Cus=Customer Focused Competency; Mea=Measurement Competency; Int= Integration and Knowledge Competency

Figure 2. The final SEM model 
Results showed there was insufficient statistical evidence to demonstrate that logistics competency directly impacted on financial performance, but logistics competency had an indirect effect on financial performance through logistics performance (indirect effect $=0.625$ ).

\section{Conclusion and implications}

When examining the 24 logistics competencies, the top three logistics competencies in Taiwanese manufacturing firms were (as shown in Table 3): (1) R12: customer focused logistics (5.55); (2) R18: broader functional assessment indexes (5.34); and (3) R11: planned customer requirement (5.28). In contrast, the three worst logistics competencies were: (1) R5: expanded integrated logistics information system (4.45); (2) R16: sharing information with customers (4.54); and (3) R8: sharing standardised information with suppliers and /or customers (4.56). The findings would imply that Taiwanese firms always focus on customer need and a comprehensive functional assessment system to measure performance. However, they still find it difficult to share standardized information and build information linkages through the supply chain.

In this study, four logistics competencies were identified in the manufacturing industry of Taiwan, namely, integration and knowledge; measurement; customer focused logistics; and agility competency. This finding also confirmed the "world-class" logistics competencies (i.e. positioning, integration, agility, and measurement) as identified by MSUGLRT (1995).

The integration and knowledge competency is a consistent set of competencies (including time-based logistics strategy and knowledge management) which clearly defines roles and responsibilities for supply chain partners, information technology, and information sharing.

The customer focused logistics competency suggests that customer requirements are regularly taken into account in strategy planning. Customer feedback and complaints are handled carefully and also become an important source of strategic competitive advantage.

The agility competency focuses on meeting rapidly changing, unplanned customer requirements and responding efficiently to unexpected circumstances.

The measurement competency signifies that those firms which have an excellent measurement system are able to measure costs, service requirements and potential growth more accurately, and thereby facilitate the management decision making process, promote coordination across functions and divisions, and benchmark specific performance metrics.

Via SEM analysis, the research findings (see Figure 1) also revealed that (1) logistics competency was significantly related to logistics performance but not significantly associated with financial performance, and (2) logistics performance was positively associated with financial performance. These findings also imply that logistics competency had an indirect effect on financial performance through logistics performance. Thus, logistics or senior managers should constantly enhance and refine their firm's four logistics competencies in relation to those of their competitors in order to acquire and maintain long-term superior logistics performance which can, in turn, lead to better financial performance.

This research has shown that logistics competency has been raised to a strategic level and has 
a significant impact on logistics performance and financial performance for acquiring sustained competitive advantage. This finding is consistent with other studies (Stank and Lackey, 1997; Morash et al., 1996; Fawcett et al, 2000; Źhao et al, 2001)

This study has utilised more rigorous statistical technologies such as CFA and SEM for hypotheses testing, which can reinforce the reliability for explanation and implication of findings.

Finally, two caveats should be stated. This study's sample was drawn from the top, largest 1,200 manufacturing firms in Taiwan and hence the conclusions inferred relate only to such firms: they should not be generalised to other small, weak or non-manufacturing firms.

All participants responded within a particular time frame and were only given a single opportunity to respond. Therefore it cannot be reliably established whether such data would hold true over time, especially in dynamic business circumstances. The performance items in this study could not reflect these varying situations.

Third-party logistics or logistics service providers play an important role in the $21^{\text {st }}$ century. However, what are their critical competencies that lead to superior logistics or financial performance? Are they different from those in the manufacturing industry? These are interesting issues worthy of future in-depth consideration.

\section{References}

Anderson, J. C. and D. W.Gerbing. 1988. Structural equation modelling in practice: a review and recommended two-step approach. Psychological Bulletin. 103(3). 411-423.

Arbuckle, J. L. 1997. Amos users' guide version 3.6. Chicago, IL: Small Waters Corporation.

Babble, E. 1998. The practice of social research, $8^{\text {th }}$ edition. London: International Thomson Publishing.

Bower, J. L. and T. M. Hout. 1992. Fast-cycle capability for competitive power. In M. Christopher ed. Logistics : The strategic issues. London: Chapman \&Hall.

Bowersox, D. J. and D. J. Closs. 1996. Logistical management: the integrated supply chain process. International editions. Singapore: McGraw-Hill.

Bowersox, D. J. and P. J. Daugherty. 1995. Logistics paradigms: the impact of information technology. Journal of Business Logistic. 16(1), 65-80.

Bowersox, D. J., D. J. Closs and T. P., Stank. 1999. $21^{\text {st }}$ century logistics: making supply chain integration a reality. Oak Brook, IL: Council of Logistics Management.

Bowersox, D. J., P. J. Daugherty, C. L. Dröge, D. S. Rogers and D. L. Wardlow. 1989. Leading edge logistics: competitive positioning for the 1990s. Oak Brook, IL: Council of Logistics Management.

Byrne, B. M. 2001. Structural equation modelling with AMOS: basic concepts, applications, and programming. New Jersey: Lawrence Erlbaum Associates. 
Chow, G., T. D. Heaver and L. E. Henriksson. 1994. Logistics performance: definition and measurement. International Journal of Physical Distribution and Logistics Management. 24(1). 17-28.

Chow, G., T. D. Heaver and L. E. Henriksson. 1995. Strategy, structure and Performance: a framework for logistics research. Logistics and Transportation Review. 31(4). 285303.

Christopher, M. 1998. Logistics and supply chain management: strategies for reducing cost and improving service. $2^{\text {nd }}$ edition. London: Financial Times-Pitman Publishing.

Christopher, M. 2000. The agile supply chain: competing in volatile markets. Industrial Marketing Management . 29(1). 37-44.

Dalton, D. R., W. D. Todor, M. J. Spendolini, G. J. Fielding and L. W. Porter. 1980. Organization structure and performance: a critical review. Academy of Management Review. 5(1). 49-64.

Daugherty, P. and P. H. Pittman. 1995. Utilization of time-based strategies: creating distribution flexibility/responsiveness. International Journal of Operations and Production Management. 15(2), 54-60.

Dess, G. G. and R. B. Robinson Jr. 1984. Measuring organizational performance in the absence of objective measures: the case of the privately-held firm and conglomerate business unit. Strategic Management Journal. 5(3). 265-273.

Ellinger, A. E., P. J. Daugherty and S. B. Keller. 2000. The relationship between marketing/logistics interdepartmental integration and performance in U.S. manufacturing firms: An empirical study. Journal of Business Logistics. 21(1). 1-22.

Ernst, D. 2000. Inter-organizational knowledge outsourcing: what permits small Taiwanese firms to compete in the computer industry? Asia Pacific Journal of Management. 17(2). 223-255.

Fawcett, S. E. and S. R. Clinton. 1996. Enhancing logistics performance to improve the competitiveness of manufacturing organizations. Production and Inventory Management Journal. 37(1). 40-46.

Fawcett, S. E. and M. B. Cooper. 1998. Logistics performance measurement and customer success. Industrial Marketing Management. 27(4). 341-357.

Fawcett, S. E., R. J. Calantone and A. Roath. 2000. Meeting quality and cost imperatives in a global market. International Journal of Physical Distribution and Logistics Management. 30(6). 472-499.

Fawcett, S. E., S. R. Smith and M. B. Cooper. 1997. Strategic intent, measurement capability, and operational success: making the connection. International Journal of Physical Distribution and Logistics. 27(7). 410-421.

Fuller, J. B., J. O'Conor and R., Rawlinson. 1993. Tailored logistics: the next advantage. Harvard Business Review. 71(3). 87-98.

Garver, M. S. and J. T. Mentzer. 1999. Logistics research methods: employing structural equation modelling to test for construct validity. Journal of Business Logistics. 20(1). 3358.

Germain, R., C. Dröge and W. Christensen. 2001. The mediating role of operations 
knowledge in the relationship of context with performance. Journal of Operations Management. 19(4). 53-469.

Gilmour, P. 1999. A strategic audit framework to improve supply chain performance. Journal of Business and Industrial Marketing. 4(5/6). 355-363.

Goldsby, T. J. and T. P. Stank. 2000. World class logistics performance and environmentally responsible logistics practices. Journal of Business Logistics. 21(2). 187-208.

Greis, N. P. and J. D.,Kasarda. 1997. Enterprise logistics in the information era. California Management Review. 39(3). 55-78.

Gunasekaran, A., C. Patel and E. Tirtiroglu. 2001. Performance measures and metrics in a supply chain environment. International Journal of Operations and Production Management. 21(1/2). 71-87.

Hair, J. F., R. E. Anderson, R. L. Tatham and W. C. Black. 1998. Multivariate Data Analysis, $5^{\text {th }}$ Edition. Prentice-Hall.

Haytko, D. L. 1994. The performance construct in channels of distribution: a review and synthesis. Proceeding of the American Marketing Association. Winter. 262-271.

Holmberg, S. 2000. A systems perspective on supply chain measurements. International Journal of Physical Distribution and Logistics Management. 30(10). 847-868.

Innis, D. E. and B. J. La Londe. 1994. Customer service: the key to customer satisfaction, customer loyalty and market share. Journal of Business Logistics. 15(1). 1-27.

Kanji, G. K. and A. Wong. 1999. Business excellence model for supply chain management. Total Quality Management. 10(8). 1147-1168.

Keebler, J. S., K. B. Manrodt, D. A. Curtsche and D. M. Ledyard. 1999. Keeping score: measuring the business value of logistics in the supply chain. Oak Brook, IL: Council of Logistics Management.

Kent Jr., J. L. 1996. Leverage2: interfunctional co-ordination between logistics and information technology. International Journal of Physical Distribution and Logistics Management. 26(8). 63-78.

Kline, R. B. 1998. Principles and Practices of Structural Equation Modelin. New York: The Guilford Press.

Koufteros, X. A. 1999. Testing a model of pull production: a paradigm for manufacturing research using structural equation modelling. Journal of Operations Management. 17(4), 467-488.

Lambert, D. M. and T. C., Harrington. 1990. Measuring nonresponse bias in customer service mail surveys. Journal of Business Logistics. 11(2). 5-25.

Lau, R. S. M. and N. M. Hurley. 2001. Creating agile supply chains for competitive advantage. Business Review. (1), 4-7.

Lin, C-H., W. S. Chow, C. N. Madu, C-H Kuei and P. P. Yu. 2005. A structural equation model of supply chain quality management and organizational performance. International journal of production economics. 96. 355-365.

Lin, C-T., H. Chiu and P-Y. Chu. 2006. Agility index in the supply chain. International Journal of Production Economics. 100. 285-299.

Lloréns, F. J., L. M. Molina and A. J. Verdú. 2005. Flexibility of manufacturing 
systems, strategic change and performance. International Journal of Production Economics. 98. 273-289.

Lynch, D. F., S. B. Keller and J. Ozment. 2000. The effects of logistics capabilities and strategy on firm performance. Journal of Business Logistics. 21(2). 47-67.

Maltz, A. and E. Maltz. 1998. Customer service in the distributor channel empirical findings. Journal of Business Logistics. 19(2). 103-130.

Mathews, J. A. and C. C. Snow. 1998. A conversation with the Acer Group's Stan Shih on global strategy and management. Organizational Dynamics. 27(1). 65-74.

Mentzer, J. T. and K. B. Kahn. 1995. A framework of logistics research. Journal of Business Logistics. 16(1). 231-250.

Mentzer, John T. and Lisa R. Williams. 2001. The role of logistics leverage in marketing strategy. Journal of Marketing Channels. 8(3/4). 29-48.

Morash, E. A. and S. R. Clinton. 1997. The role of transportation capabilities in international supply chain management. Transportation Journal. 36(3). 5-17.

Morash, E. A., C. L. M. Dröge and S. K. Vickery. 1996. Strategic logistics capabilities for competitive advantage and firm success. Journal of Business Logistics. 17(1) 1-22.

MSUGLRT(Michigan State University Global Logistics Research Team). 1995. World class logistics: the challenge of managing continuous change. Oak Brook, IL: Council of Logistics Management.

Nanda, A. 1996. Resources, capabilities and competencies. In B. Moingeon and A. Edmondson eds. Organizational learning and competitive advantage. CA: Thousand Oaks. SAGE.

Nevitt, J. and G. R. Hancock. 2001. Performance of Bootstrapping approaches to model test statistics and parameter standard error estimation in structural equation modeling. Structural Equation Modeling. 8(3). 353-377.

Novack, R. A., L. M. Rinehart and C. J. Langley Jr. 1994. An internal assessment of logistics value. Journal of Business Logistics. 15(1). 113-152.

Novack, R., Rinehart, L.,Wells, M., 1992. Rethinking concept foundations in logistics management. Journal of Business Logistics 13(2), 233-68.

Olavarrieta, S. and A. E. Ellinger. 1997. Resource-based theory and strategic logistics research. International Journal of Physical Distribution and Logistics Management. 27(9/10). 559587.

PRTM Consulting, 1994. Integrated-supply chain performance measurement: a multi-industry consortium recommendation. Weston, Mass: PRTM.

Rogers, D. S., P. J. Daugherty and A. E. Ellinger. 1996. The relationship between information technology and warehousing performance. Logistics and Transportation Review. 32(4). 409-421.

Roth, P. L. 1994. Missing data: a conceptual review for applied psychologists. Personnel Psychology. 47. 537-560.

Saunders, M. N. K., P. Lewis and A. Thornhill. 2000. Research Methods for Business Students. $2^{\text {nd }}$ Edition. London: Person Education Limited.

Spriggs, M. T. 1994. A framework for more valid measures of channel member performance. Journal of Retailing. 70(4). 327-343. 
Stank, T. P. and C. W. Lackey Jr. 1997. Enhancing performance through logistical capabilities in Mexican maquiladora firms. Journal of Business Logistics. 18(1). 91-123.

Stock, J. R. 1990. Managing computer, communication and information technology strategically: opportunities and challenges for warehousing. Logistics and Transportation Review. 26(2). 133-148.

Stock, J. R. and D. M. Lambert. 1992. Becoming a 'world-class' company with logistics service quality. International Journal of Logistics Management. 3(1). 73-81.

Tan, K-C, V. R. Kannan, R. B. Handfield and S. Ghosh. 1999. Supply chain management: an empirical study of its impact on performance. International Journal of Operations and Production Management. 19(10). 1034-1052.

Tracey. 1998. The importance of logistics efficiency to customer service and firm performance. International Journal of Logistics Management. 9(2). 65-81.

Venkatraman, N. and V. Ramanujam. 1986. Measurement of business performance in strategy research: a comparison of approaches. Academy of Management Review. 11(4). 801-814.

Vickery, S., R. Calantone and C. Dröge. 1999. Supply chain flexibility: an empirical study. The Journal of Supply Chain Management. 35(3). 16-24.

Vickery, S. K., C. Dröge anf R, E. Markland. 1993. Production competence and business strategy: do they affect business performance. Decision Sciences. 24(2). 435-455.

Weisberg, H. F., J. A. Krosnick and Bruce D. Bowen. 1996. An introduction to survey research, polling, and data analysis. $3^{\text {rd }}$ edition. London: SAGE.

Whitehill, M. 1997. Knowledge-based strategy to deliver sustained competitive advantage. Long Range Planning. 20(4). 621-627.

Yusuf, Y. Y., M. Sarhadi and A. Gunasekaran. 1999. Agile manufacturing: the drivers, concepts and attributes. International Journal of Production Economics. 62(1/2). 33-43.

Zhang, Z. and H. Sharifi. 2000. A methodology for achieving agility in manufacturing organisations. International Journal of Operations and Production Management. 20(4). 496-512.

Źhao, M., C. Dröge and T. Stank. 2001. The effects of logistics capabilities on firm performance: customer-focused versus information-focused capabilities. Journal of Business Logistics. 22(2). 91-107. 